\title{
Impact of Globalization on Nigeria Education System: Challenges in the New Millennium
}

\section{Ndanusa Mohammed Manzuma-Ndaaba}

\author{
School of Business Innovation and Technoprenuership, University Malaysia Perlis \\ Mnzuma1@gmail.com \\ Yoshıfumi Harada(PhD)
}

School of Business Innovation and Technoprenuership, University Malaysia Perlis yoshifumi@unimap.edu.my

\author{
Abd. Rahım Romle (PhD) \\ College of Law, Government and International Studies, Universiti Utara Malaysia \\ abd.rahim@uum.edu.my
}

\author{
Abdul Shukor Shamsudin (PhD) \\ School of Business Management, COB, Universiti Utara Malaysia \\ shukor@uum.edu.my
}

\section{Doi:10.5901/mjss.2016.v7n1p89}

\section{Abstract}

\begin{abstract}
Internationalization of higher education is one of the dynamism of globalization which has reduced institutions of higher learning to a global village by facilitating teaching and learning across Nations and Continents. Not fewer than 4.3 million students chose to study abroad in 2011 and projected to increase to approximately 5.8 million by the year 2020. The trend now is that international certificate is seen as a symbol of prestige worldwide with the development of knowledge based economy. The purpose of this paper is to conceptualize the push-pull factors of Nigerian international students resulting from ill-conceived and poorly implemented educational policies from colonial era in the Federal Republic of Nigeria and the multiplier effects on the economy and the system. The consequences of these policy summersault is the brain drain which has implications on the society with loss of trained, skilled, competent and qualified professionals needed for economic rejuvenation. It serves as clarion call to the Government of Nigeria to be proactive on international student mobility policy. The paper was based on the reviews of Nigeria educational policies, relevant literatures and internet publications on international higher education, industry reports and international organizations statistics.
\end{abstract}

Keywords: Internationalization, globalization, push-pull factors, brain drain, Nigeria educational policies, Federal Republic of Nigeria.

\section{Introduction}

The internationalization of education has put universities on their toes, designing and aliening their curriculum, programs and administration to retain local students and also attract foreign students. These challenges are seen as two edge sword possessing both weaknesses as well as strengths for higher education systems around the world (Arambewela \& Hall, 2009; Mcmahon, 1992). Internationalization is the process of weaving academic programs, institutions and their quality into the global context (Altbach \& Knight, 2007; Kwon, 2013). While globalization is the reality of the new millennium where information communication technology (ICT) brought the world to our door step (Altbach \& Knight, 2007).

Drucker (1997) has boldly predicted the demise of "traditional universities" with the growth of technology and globalization via open and online universities. International education is multi- dimensional concept subjecting the students, the academic programs or the institutions to mobility (Mcmahon, 1992; Naidoo, 2006; Vincent-Lancrin, 2008; ERI/UNESCO 2013; Sinlarat, 2013). The volume of movement has greatly increased, and this affects the demand and the supply side of the government. And consequently change the position of government from giving aids, grants and scholarship to regulator or facilitator and also change the perception of institutions to quasi-commercial service providers 
to achieve sustainable competitive advantage in a global education environment (Sheu, 2011; Knight, 2004; Brookes, 2003). Mazzarrol \& Soutar (2002) draw the attention of institutions willing to embark on international services to be conscious of their opportunities and threats within the market environment.

The focus of this study is to give credence to the fact that those intellectual leakages are result of policy summersault which has negative effects on the country's economy. The study further examined some critical factors that push Nigeria students outward, reviewed some of the likely motivating pull factors an average Nigeria student required in foreign land, analyze the factors that affect Nigerian students intentions not to return to their home country after studies, and the consequences of this attitudinal behavior on the Nation.

\section{Nigeria Educational Policies}

Education is critical for long- term success of any Nation including Nigeria. The country's ability to stay competitive in a knowledge driven-world is dependent on the development of the right skills at different levels of human endeavors. At the moment, the challenges of doing this is quite immense because Nigeria is decades behind in the provision of ideal environment for the development of required skills (Nigeria Federal Ministry of Education 2012). Nigeria educational policy was marred with a lot of inconsistences, non- continuity, policy summersault and instability in government. The entire aforementioned are attributes of third world countries including Nigeria (Tikly, 2001). Nigeria with an estimated population of over 160 million people (according to 2006 population census figure) has an asset that can move the country forward by galvanizing other sectors of the economy. However, this large population is at the moment considered a liability or time bomb waiting to explode and can only be truly an assets if nurture through quality education which is now the key index for measuring development globally (Odukoya, 2009). However, some peculiarities of each nation must be taken into consideration in terms of economic stability, democratic practices, traditional and civilization level before assessing the literacy policies of the country (Green, 1997).

\subsection{Educational Policies Under Colonial ERA}

The amalgamation of Northern and Southern Nigeria by the Sir Lord Luggard Colonial administration of 1914 saw the emergence of Educational policies at the pleasure of the ruling government. The expansion of education policy to accommodate citizen's views and ideas in Nigeria begins in 1944 as a fall out of nationalist movement. The struggle by the founding fathers led to the promulgation of the first education law for the entire country; the educational ordinance of 1948 which allowed regional government to administer education according to their peculiarities in Nigeria (Imam, 2012).

\subsection{Educational Policies at Independence}

The policy at independence focuses on replacement of British administrators with the indigenous manpower especially in schools and the civil service (Woolman, 2001). The first indigenous National policy on Education in Nigeria was launched in 1977 with a clear mandates to correct all the social imbalances created in the colonial policies and then transform individual, society and the Nation at large into morally, socially and scientific institution geared towards self-realization and National unity (Amaghionyeodi \& Osinubi, 2006). Education was viewed as a social service and investment in manpower needed for economic transformation and given top priority by the government in this indigenous frame-work (Taiwo, 1980). The infrastructural inadequacy and high level of underdevelopment in Nigeria was to be address by the 1977 policy. In order to achieve the objectives, the policy made education in Nigeria the Federal Government's responsibility in terms of centralized control and funding of education (Imam, 2012). The unique feature of the policy was the imitation of 6-3-3-4 educational system modeled after the American system (Nwagwu, 2007). The policy was designed as follows: 6 years primary school, 3 years junior secondary school, 3 years senior secondary school, and 4 years tertiary institution.

\subsection{Educational Policies Under Civilian Administration}

The 1979 Constitution necessitated the revision of the educational policy to conform to the democratic principles and the ruling party's manifesto (National Party of Nigeria NPN). Some of the provisions of the revised policy were the introduction of compulsory universal primary Education (UPE) and prescription that all Nigerian children are encourage to learn at least one of the three major indigenous languages of Hausa, Igbo or Yoruba (Federal Republic of Nigeria, 1979). The Constitution (Federal Republic of Nigeria, 1999) under a civilian administration launched the Universal Basic 
Education (UBE) Scheme with the aim of reducing the illiteracy level to lowest minimum and jack up Nigeria's ability to read and write to 70\% by 2003 (Federal Republic of Nigeria, 1999). It also aimed at using education to addressed problem of mutual suspicion and distrust among the citizens thereby fostering unity and national integration devoid of prejudice hitherto associated with previous policies (Imam, 2012).

\section{The Current Policy}

The current Nigeria Education policy is the revised fourth edition which captured the interest of children recognized as having special needs, those physically challenged and disable or handicapped. It also provide for integration of Qur'anic school program as well as programs for out of school children with particular interest on 'Almajiri '(itinerant pupil). The menace of almajiri school system has constituted security risk in the North by exposing pupil to social evils at a tender age (Imam, 2001). The Obasanjo, administration launched the Almajiri school program in Sokoto in 2005 as part of the revised policy and also strengthen the 9-3-4 system through millennium development goals initiatives, almost ten (10) years after little or no progress was made on the integration of Almajiri into regular curriculum. This policy merged the 6 years primary and 3 years junior secondary school to a compulsory and free 9 years program wholly sponsored by the Government, while 3 years senior secondary and 4 years tertiary will be finance by the parents.

In Nigeria, English language is adopted as the lingua-franca. However, the national policy encourages the use of at least one of the mother tongue languages in line with the country's cultural policy which sees native language as a vehicle for cultural expression and transmission (Ernest Samuel, 2010).

\section{Tertiary Education in Nigeria}

In Nigeria, tertiary education refers to an advance learning above the secondary school. These included mono-technics, polytechnics, colleges of Education and universities (Amaghionyeodiwe, \& Osinubi, 2006). The average year to obtain an NCE certificate is 3 years. The Nigeria polytechnic education is divided into two: The first two years lead to the award of Ordinary National Diploma (OND), there after a compulsory 1 year industrial attachment is a prerequisite for admission into the second two years program. The second 2 years program lead to the award of Higher National Diploma (HND). The university system in Nigeria until recently was an exclusive responsibility of the Government (Fabunmi, 2005). The duration for an award of a bachelor degree is in the range of 4 to 6 years depending on the field of study. Holders of HND and bachelor degree within 30 years of age are mobilized for compulsory 1 year National Youth Service Corp (NYSC) scheme. Nigeria has about 106 universities both public and private made up of 42 federal, 38 State and 26 privates (NUC, 2014).

The financial commitment of the Nigeria Government to Education has being fluctuating since the advent of democracy in 1999 (Fafunwa, 2004). However, the Educational system is on concurrent legislative list, but the Federal Government interest on tertiary Education is more pronounced. Table 1, shows the budgetary provision for various levels of education from 1999 to 2002 shared among 26 Federal Universities, 16 Federal polytechnics and 20 Federal colleges of Education.

Table 1: Federal Government Expenditures share by level of Education, 199-2002

\begin{tabular}{|l|c|c|c|c|}
\hline Institutions & 1999 & 2000 & 2001 & 2002 \\
\hline Universities & 39.9 & 49.2 & 39.6 & 51.2 \\
\hline Polytechnics & 18.5 & 17.0 & 16.6 & 16.0 \\
\hline Coll. Of Education & 10.6 & 9.6 & 11.9 & 9.7 \\
\hline Secondary School & 18.7 & 15.3 & 15.5 & 15.6 \\
\hline Primary School & 12.2 & 8.9 & 16.4 & 7.7 \\
\hline
\end{tabular}

Source: Federal Government of Nigeria, Annual Budget (various years).

\section{Conceptual Frame Work}

Altbach (1998) presented the push-pull model for international student mobility. His argument was based on two-way traffic approach. While the operating environment at home is not conducive and threatens continuous stay of students, the host communities are extending appealing hands of fellowship to potential students. This is similar to preservation 
and self- determination goals postulated by Chirkov et al. (2007) in line with the argument of self-determination theory researchers (Deci \& Ryan, 1985, 2002; Ryan \& Deci, 2000, 2004).

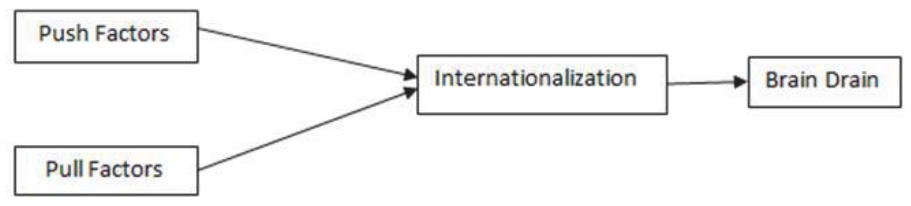

Figure 1: The conceptual framework

\subsection{Push Factors}

As claimed by Mazzarol \& Soutar (2002) whose work is scholarly recognized and referenced in most studies on push-pull factors and student mobility, identified some push factors as the student's impression of foreign courses placed higher than local programs, limited and keenly contested space at home institutions, desire to change environment and use education as a starting point for eventual migration. In another research conducted by Mazzarol (1998) confirmed that aside the aforementioned factors, situations such as law and order, technological innovation, and competitive. In Nigeria case quota system admission policy of universities, mind set to relocate from the home country, limited areas of study and specialization at home universities are some of the visible factors pushing students outward. Other push factors according to extent literature are: fewer world class institutions, lack of doctoral and postdoctoral programs (Altbach, 2004), limited availability of specialization (Altbach, 2004; Safahieh \& Singh, 2006), limited access to funding and poor career prospects (Altbach, 2004; Maringe \& Carter, 2007; Vo et al., 2009; Eder et al., 2010; Jack \& Schapper, 2012). In Nigeria context, some of the factors are similar with only some peculiarities of African continent such as inconsistence National policy on education discussed above, political instability, poverty and unemployment, insecurity and the unpleasant Education atmosphere at home which are direct consequences of policy inconsistences and poor implementation. These institutional challenges coupled with individual's factors resulted into foreign studies by the few privilege families and individuals.

\subsection{Pull Factors}

Mazzarol \& Soutar (2008) found that possible pull factors for international students could be either the country's factors or the institution's attributes. In the country's perspective general macro-economic issues such as security, cost of living, level of infrastructural development, visa policy, religion, weather condition, culture/ people and the image of the destination are the first considerations (Veloutsou et al., 2005; Arambewela, 2003; International Development Programs (IDP), 1995). Then the university's attributes which are the micro-economic variables of the potential student like prestige, reputation, study programs, tuition fees, supporting services, learning environment, quality of teaching, teaching techniques and skills, status of the certificate and serenity of the university environment (Eder et al.,2010; Vo et al., 2009; Smith et al., 2002; Townley, 2001; Geall, 2000; DETYA, 2000; Burke, 1986). There are no literatures to support why Nigerian students choose their study destination and or institution; however, most of the analyzed factors are justifications for an average Nigeria student to study in a country. Maringe and Carter (2007) study on African students in United Kingdom concluded that Africans which Nigeria represent used higher education as a training ground for leadership positions when they return home.

The volume of Nigerian students studying outside the shore of the country is alarming. For instance in 2008/2009 nearly 15,000 Nigerian students are in UK as shown in table 2. Moreover, the trend is now towards Asia and the pacific with Singapore, Malaysia and Republic of Korea as emerging contenders (Lasanowski, 2009), the total number globally could be heartbreaking and its consequences can only be imagine if they refuse to return after studies (Olanrewaju, Abiodun \& Olugboyega, 2010) 
Table 2: Top five non-EU countries of domicile in 2008/09 for HE students in UK Higher Education Institutions

\begin{tabular}{lccc}
\hline Country of domicile & $\mathbf{2 0 0 7 / 0 8}$ & $\mathbf{2 0 0 8 / 0 9}$ & \% change \\
\hline China & 45355 & 47035 & $3.7 \%$ \\
India & 25905 & 34065 & $31.5 \%$ \\
Nigeria & 11785 & 14380 & $22.0 \%$ \\
United States & 13905 & 14345 & $3.2 \%$ \\
Malaysia & 11730 & 12695 & $8.3 \%$ \\
\hline
\end{tabular}

Source: HESA, students in Higher Education institution 2007/08, 2008/09.

Table 3, shows the change in trend towards Asia. Malaysia alone garnered almost 6,000 Nigerian students in 2009 emerging as the fourth source country (Morshidi, Rosni \& Koo, 2013).

Table 3: Malaysia's top five source countries of International Students, December 2009

\begin{tabular}{|c|l|c|c|c|}
\hline No & Countries & (Public)IPTA & (Private)IPTS & Total \\
\hline 1 & Iran & 4,002 & 6,930 & 10,932 \\
\hline 2 & Indonesia & 3,713 & 6,099 & 9,812 \\
\hline 3 & China & 2,099 & 7,078 & 9,177 \\
\hline 4 & Nigeria & 571 & 5,398 & 5,969 \\
\hline 5 & Yemen & 1,549 & 3,382 & 4,931 \\
\hline
\end{tabular}

Source: MOHE Malaysia 2009, as reported by Jani (2010)

\section{The Brain Drain}

'Brain drain' is a situation where talents flow across international boundaries in search of adequate engagement and reward for their skills, qualifications, and competence. The issue of brain drain is not restricted to developing-developed countries, sometimes it happens within developed nation or even within emerging economy or the third world countries (Gatley, Lessem \& Altman, 1996). Incidentally, there are cases of movement from developed nation to explore the developing nations based on economic reasons and decide not to return to their home country (Baruch, Budhwar \& Khatri, 2007). Nigeria student in any part of the world including Sub Sahara African countries maximized the advantage of study abroad and never dream of returning home after studies, at least not immediately. Rather, thoughts of either staying permanently, for some time or migrating to another country all in search of greener pasture used to be their focuses. This mindset adversely affects the manpower potentials of Nigeria.

The brain drain usually drains developing countries and gains developed countries by contributing to the human capital of developed countries thereby making them richer and disadvantaged developing countries by making them poorer (Geesen, 1998). The increasing out flow established a parasitic relationship where one gain and the other lose. This phenomenon is not healthy for the survival of the economy of donor countries (Davenport, 2004).

The significant of this study is to reawake the consciousness of Nigeria policy makers to factor in some of the motiving pull factors and also address some of the push factors discussed with the view to retain both the students and professionals at home for a brighter economic prosperity.

\subsection{Baruch Adapted Model on Brain Drain}

Based on the above discussion on research issues, we now present the adapted model in Fig. 2. This model presents a comprehensive perspective of the factors that influence the decision of most international students including Nigerian students either to stay in the host country or return to the home country. The model is an adaption from the work of Baruch, et al.(2007). It is assumed from the research issues that the independent variables as tested in Baruch work are: adjustment process; satisfaction with the university; social supports from the host community and the people; families' ties from either the host country or home country and lastly the demographic factors. The dependent variable according to this model is the intention to stay at host country after study and is being moderated by the effect of labor market and home national culture. 


\subsection{Baruch Model of Brian Drain}

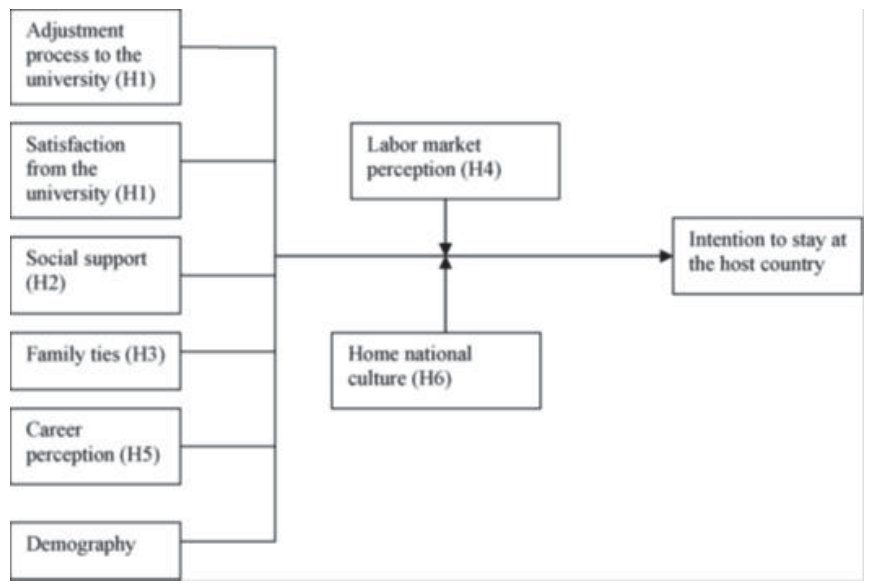

Figure 2: Factors influencing the decision to stay abroad.

\section{Findings from the Theory}

From the model of brain drain above, it is clear that Nigerian students that surgeon on foreign studies easily adjusted to their study environment, satisfied with the learning process, enjoyed social support, get means of livelihood, established link and tend to remain even after completion of studies (Baruch et al., 2007). If the pushed factors are not address at home the volume of students seeking foreign studies will not abate in nearest future and the adverse effect will be heavy on the Nation because foreign education purse is tied to brain drain (Kar-yiu \& Chong, 1999). Similarly, the pull factors from these countries are "Greek gift" aimed at attracting cheap but efficient human resources for the development of their own economy at the expense of source countries (Lasanowaski, 2009). Therefore, policy makers should be aware of the dangers ahead if left unabated.

\section{The Implications For Nigeria}

In 2009, around 3.7 million foreign tertiary education students were enrolled outside of their country of origin, up from 3.5 million in 2008 and 3.2 million in 2007. The number of foreign students increased from 2.1 to 3.7 million during the ten year period from 2000 to 2009, representing annual average growth of 6.6 percent per year (OECD, 2010, Australian Education International 2011; OECD, 2012). Going by this global trend and the mind set of Nigerian international students, it will be an understatement to say that Nigeria is at the verge of losing great assets for national development to internationalization and brain drain. This study has a lot of positive implications for the host countries in terms of economic and social benefits. On the other hand, the study highlighted some critical issues that would be of concern to Nigeria and other source countries, to reduce the tide of this perpetual disappointment whenever their citizens travel for overseas courses and decide to stay back. Another significant of this study to the society is that returned students and scholars play a leading role in areas like education, science and technology, high-tech industries, finance, insurance, trade and management and serve as a driving force for the country's economic and social development and this new dimension to the wave of talent flow is called brain gain (Changjun, 2013).

\section{Conclusion and Recommendation for Further Research}

Education in Nigeria until recently is more of a social service and responsibility of government through direct funding and dynamic intervention initiatives (Federal Republic of Nigeria, 1979). The development of education is the foundation for the development of any economy. This study agrees with the findings in many literatures that the country choice of Nigeria students is a combination of the interaction of micro (private) and macro (public) dynamics of the individual and the countries involved ( Chen \& Zimitat, 2006; Li \& Bray 2007; Davidson \& Wang 2008; Vo et. al.2009; Eder et al., 2010). 
In Nigeria today, most of our best eleven are professionals and expatriates working in different parts of the world in which significant number got there via internationalization or globalization. These researchers therefore recommend that Nigeria must design some deliberate policy to combat the attrition rate by putting in place a reward mechanism for those that choose to return, improve the quality and standard of education at home country to world class status and erect some international bureaucratic barriers that could discourage foreign studies and enhance effective utilization of human mental resources within the knowledge economy. Since the work is conceptual, it recommends an empirical validation of actual number of Nigerians lost in this phenomenal. Also recommend a study on the real push-pull factors of Nigerian international students.

\section{References}

Amaghionyeodiwe, L.A and Osinubi, T.S.(2007). "Do Higher Levels Of Schooling Lead To Higher Returns To Education In Nigeria?" Applied Econometrics and International Development, Vol.7-1. pp.157-164

Arambewela, R \& Hall, J. (2009), A model of student satisfaction: International postgraduate students from Asia. European Advances in Consumer Research, 8, 129-135

Arambewela, R.A. (2003), "Post-choice satisfaction of international postgraduate students from Asia studying in Victorian universities" doctoral thesis, Victoria University, Melbourne

Altbach, P.G. (1998). Comparative Higher Education: Knowledge, the University, and Development. Hong Kong: Comparative Education Research Centre, The University of Hong Kong.

Altbach, P.G. (2004), 'Higher education crosses borders', Change 36(2), 18-24.

Altbach, P.G and Knight, J. (2007), The Internationalization of Higher Education: Motivations and Realities. Journal of Studies in International Education, Vol. 11, No. 3/4, pp. 290-305.

Baruch, Y. Budhwar, S. P. \& Khatri (2007): Brain drain: Inclination to stay abroad after studies. Journal of world business 42, pp 99-112

Brookes, M., (2003), Higher education: marketing in a quasi-commercial service industry, international journal of Nonprofit and voluntary sector marketing, 8(2), 134-142.

Changjun, Yue (2013): International student mobility: China. ERI/UNESCO @2013

Chen, C. H \& Zimitat C. (2006). Understanding Taiwanese students' decision-making factors regarding Australia international higher education. Int. J. Educ. Manage., 20(2): 91-100

Chirkov, V. I., Vansteennkiste, M., Tao, \& Lynch, M (2007), The role of motivation to study abroad in the adaptation of international students: A self-determination theory approach. International journal of intercultural relations, 31 (2), 199-222

Davenport, S (2004). Panic and panacea: Brain drain and science and technology human capital policy. Research Policy, 33: 617-630

Drucker, P. (1997) "Still the youngest mind",Forbes, 10 March.

Eder, J., Smith, W.W. \& Pitts, R.E. (2010). 'Exploring Factors Influencing Student Study Abroad and Destination Choice', Journal of Teaching in Travel \& Tourism, 10 (3), 232-250

Ernest Samuel, G. C. (2010): Towards the implementation of the Nigeria cultural policy for the promotion of culture in Nigeria.

Fabunmi, M. (2005), Historical Analysis of Educational Policy Formulation in Nigeria: Implications for Educational Planning and policy. International Journal of African and African American Studies, 4(2), 1-7.

Fafunwa, A. B. (2004). History of Education in Nigeria, Ibadan: NPC Educational Publishers Ltd.)

Federal Republic of Nigeria (1979): Constitution of the Federal Republic of Nigeria

Federal Republic of Nigeria (1999): Constitution of the Federal Republic of Nigeria.

Geall, V. (2000), "the expectations and experience of first year students at City University of Hong Kong", Quality in Higher Education, Vol. 6 No. 1, pp. $77-89$

Green, A. (1997). Education and Globalization in Europe and East Asia: Convergent and Divergent Trends. Journal of Education Policy, $14,55-71$

HESA/UNESCO, (2013): Higher education statistics agency, Students in higher institutions. www.hesa,uc.uk/index

Imam, H. (2001): The Cultural Practice of Almajirci Education and its Socio-Political Implication. Journal of Development and Society, 1(3), 46-53.

Imam, H. (2012) Educational Policy in Nigeria from Colonial Era to the Post-Independence period

Jani, Rohana (2010): International students view of Malaysia Higher Education: Internationalization and Marketing of Higher Education in Malaysia Seminar 2009.

Kar-yiu, W., \& Chong, K. Y. (1999): Education, economic growth, and brain drain. Journal of Economic Dynamics and Control, 23: 699725

Knight, J. (2004), Internationalization remodeled: Definition, Approaches, and Rationales, Journal of Studies in International Education, Vol. 8, No. 1, pp. 5-31

Kwon, Ki-Seok (2013): International student mobility: Republic of Korea. ERI/UNESCO @2013

Lasanowaski, V. (2009), International Student Mobility: Status Report 2009. The Observatory on Borderless Higher Education

Li, M., \& Bray, M. (2007): Cross-border flows of students for higher education: Push-pull factors and motivations of mainland Chinese students in Hong Kong and Macau. Higher Education, 53, 791-818

Naidoo, V. (2006), "International education, an tertiary level update", Journal of Research in International Education, Vol. 5 No. 3, pp. 
323-45

Maringe, F. \& Carter, S. (2007): International students" motivations for studying in UK HE. International Journal of Educational Management, 21(6), 459-475

Mazzarol, T. \& Soutar, G. N. (2002): Push and pull factors influencing international student destination choice. The International Journal of Educational Management, 16(2): 82-92.

Mazzarol, T.W., (1998), Critical success factor for international education marketing, International Journal of Education Management, 12(4): $163-175$

Mazzarol, T. \& G.N. Soutar, (2008): The global market for higher education: Sustainable competitive strategies for the new millennium. Edward Elgar Publishing, Cheltenham.

Mazzarol, T., G.N. Soutar \& V. Thein,( 2000): Critical success factors in the marketing of an educational institution: A comparison of institutional and student perspectives. Journal of Marketing for HE, 10(2): 39-51

McMahon, M., 1992, 'Higher Education in a World Market: A Historical Look at the Global Context of International Study', Higher Education, 24 (2), 465-82

Morshidi, S., Rosni, B. \& Koo Yew Lie (2013): International student mobility: Malaysia. ERI/UNESCO @2013

Odukoya, D. (2009) Formulation and Implementation of Educational Policies in Nigeria, Educational Research Network for West And Central Africa (ERNCAWA), www.slideshare.net..

Olanrewaju, O., Abiodun, S. B. \& Olugboyega, A. O. (2010), GATS and Higher Education in Nigeria: A preliminary investigation of the indicative patterns of consumption abroad by Nigerians. JHEA/REASA Vol.8 No 1, 2010 pp 99-122.

Sinlarat, Paitoon (2013): International student mobility: Thailand. ERI/UNESCO @2013

Tikly, L. (2001): Globalization and Education in the Postcolonial World; Towards a Conceptual Framework. Comparative Education, $37(2), 151-171$.

Sheu, T. S. (2011), A comprehensive model for explaining university students' favorable behavioral intentions: Journal of quality Vol.18, No 1 (2011).Varghese, N.V. 2008: Globalization of Higher Education and Cross-border Student Mobility. Paris, UNESCO International Institute for Educational Planning

Veloutsou, C., Paton, R.A. and Lewis, J. (2005), "Consultation and reliability of information sources pertaining to university selection", International Journal of Educational Management, Vol. 19 No. 4, pp. 279-91

Vincent-Lancrin, S. (2008), Student Mobility, Internationalization of Higher Education and Skilled

Migration, World Migration, Paris, OECD.

Vo, M., Muntasira, R. \& Jiang, M., 2009, 'Push-pull Factors Influencing Exchange Students' Destination Choice for Study Abroad: A Case Study of the Students at JIBS', University Essay, Jönköping University, Jönköping International Business School accessed at http://hj.diva-portal.org/smash/record.jsf? pid=diva2:225442.

Woolman, D.C. (2001). Educational Reconstruction and Post-Colonial Curriculum Development: A Comparative Study of Four African Countries. International Education Journal, 2(5), 27-46. 